\title{
The analysis of Treg lymphocyte blood percentage changes in patients with head and neck cancer during combined oncological treatment: a preliminary report
}

\author{
MAGDALENA DUTSCH-WICHEREK ${ }^{1}$, KATARZYNA CHABEREK ${ }^{2}$, ADRIANNA MAKAREWICZ2,3, \\ ANTONI SIERANT ${ }^{2}$, JACEK WITWICKI ${ }^{2}$ IRENEUSZ BIELECKI ${ }^{4}$, EUKASZ WICHEREK ${ }^{2}$ \\ ${ }^{1}$ Center of Postgraduate Medical Education (CMKP), Warsaw, Poland \\ ${ }^{3} 2^{\text {nd }}$ Department of Obstetrics and Gynaecology, Center of Postgraduate Medical Education (CMKP), Warsaw, Poland \\ ${ }^{3}$ Lukaszczyk Oncological Center in Bydgoszcz, Bydgoszcz, Poland \\ ${ }^{4}$ Department of Pediatric Otolaryngology, Head and Neck Surgery, Department of Paediatric Surgery, Medical University of Silesia, \\ Katowice, Poland
}

\begin{abstract}
Introduction: In patients with cancer, Treg lymphocytes seem to play an important role in promoting tumour growth. The number of circulating Treg cells has been associated with poor survival among patients suffering from various types of cancers. The aim of the present study was to evaluate the changes in the percentage levels of Treg lymphocytes in the blood samples of patients with head and neck cancer during combined treatment with respect to the stage of the disease and the intensity of the radiation reaction as monitored using the Dische scale.

Material and methods: Peripheral blood samples were collected from 20 head and neck cancer patients prior to the combined oncological treatment, during, and then one week after the completion of the therapy.

Results: A statistically significantly higher percentage of $\mathrm{CD}^{+} / \mathrm{CD}^{+} / \mathrm{CD} 25^{+} / \mathrm{FoxP} 3^{+} / \mathrm{CD} 127(-/ \mathrm{low})$ $T$ cells within the $\mathrm{CD}^{+} / \mathrm{CD}^{+} \mathrm{T}$ cell population was detected in patients during radiotherapy $(\mathrm{RTH})$, chemotherapy $(C T H)$, and chemoradiotherapy $(C R T)$ than before the treatment began $(p<0.0001)$. A statistically significantly higher percentage of $\mathrm{CD}^{+} / \mathrm{CD}^{+} / \mathrm{CD} 25^{+} / \mathrm{FoxP} 3^{+} / \mathrm{CD} 127(-/$ low) $\mathrm{T}$ cells within the $C D 3^{+} / C D 4^{+} T$ cell population was detected after RTH/CRT than before treatment, with respect to the radiation reaction as evaluated using the Dische scale $(p=0.0150)$.

Conclusions: The increase in the percentage of Treg cells correlated with an increase in the intensity of the radiation reaction measured using the Dische scale which indicates the advance of the oral mucositis reaction to RTH. In conclusion, because the role of Treg lymphocytes in cancer patients is complex, it is necessary to monitor the percentages of these cells in patients during combined oncological therapies.
\end{abstract}

Key words: radiotherapy (RTH), Treg cells, head and neck cancer, Dische scale.

(Centr Eur J Immunol 2020; 45 (4): 409-413)

\section{Introduction}

Head and neck squamous cell carcinoma is a highly immunosuppressive malignancy [1]. The tumour microenvironment in patients with head and neck cancer imposes a strong immunosuppressive effect through soluble and cell-associated inhibitory mediators and the recruitment of host immunosuppressive cells such as Treg lymphocytes, which are responsible for maintaining the immune response [1-4]. In patients suffering from head and neck squamous cell carcinoma the increase in the Treg cell blood percent- ages with a corresponding decrease in the lymphocyte level, without normalisation after treatment [5], as well as an increase in the number of $\mathrm{CD}^{+} \mathrm{T}$ cells undergoing apoptosis have been observed [6]. Even following the completion of treatment, defects in signalling [7] constituted a permanent effect in these patients [8]. The influence of chemoradiotherapy (CRT) on lymphocytes has been observed in patients with various types of cancer $[9,10]$. Schuler et al. have suggested that CRT induces tissue changes that influence the survival of Treg lymphocytes and preserve their

Correspondence: Assoc. Prof. Magdalena Dutsch-Wicherek, Jagiellonian University, e-mail: magdalena.dutsch-wicherek@uj.edu.pl Submitted: 14.09.2020; Accepted: 5.10.2020 
Table 1. Characteristics of the patients with head and neck cancer

\begin{tabular}{lc}
\hline Characteristics & $\boldsymbol{n}$ \\
\hline Number of patients & 20 \\
\hline Women & 4 \\
\hline Men & 16 \\
\hline Age - average & $32-67$ \\
\hline Men & 48.2 \\
\hline Women & 55.2 \\
\hline Localization of tumour & 9 \\
\hline Oropharynx & 11 \\
\hline Hypopharynx and larynx & \\
\hline Tumour stage according to TNM 2010 & 16 \\
\hline III & 4 \\
\hline IV
\end{tabular}

\begin{tabular}{lc}
\hline Lymph node status & \\
\hline $\mathrm{N} 0$ & 3 \\
\hline $\mathrm{N}+$ & 17 \\
\hline Tumour grade & \\
\hline Grade 1 & 0 \\
\hline Grade 2 & 12 \\
\hline Grade 3 & 8 \\
\hline
\end{tabular}

\begin{tabular}{ll}
\hline Type of treatment & \\
\hline Surgery & 16 \\
\hline Radiotherapy & 20 \\
\hline Adjuvant chemotherapy & 11 \\
\hline Induction chemotherapy & 6 \\
\hline$T N M$ - tumour, node, metastasis.
\end{tabular}

TNM - tumour, node, metastasis.

\section{TREATMENT}

$\begin{gathered}20 \\ \text { patients }\end{gathered} \rightarrow \begin{gathered}1^{\text {st }} \\ \text { sample }\end{gathered} \rightarrow \begin{gathered}2^{\text {nd }} \\ \text { sample }\end{gathered} \rightarrow \begin{gathered}3^{\text {rd }} \\ \text { sample }\end{gathered}=\begin{gathered}60 \\ \text { samples }\end{gathered}$

Fig. 1. The graphically presented process of blood sample collection

suppressor function [10]. It has been shown that radiotherapy (RTH) affects the function of the immune system and enhances the innate and adaptive immune response, the socalled abscopal effect. Moreover, an increase in the number of Treg cells after radiation in animals and humans has been demonstrated in several studies [11, 12]. Such studies have shown that Treg cells are more resistant to irradiation than other lymphocytes. Additionally, a preferential RT-induced proliferation of Treg lymphocytes with preserved suppressive function has been observed [13, 14]. Chemoradiotherapy and RTH were observed to reduce the number of $\mathrm{CD}^{+}$ $\mathrm{T}$ cells and to increase the percentage of Treg cells in various studies [10]. Advanced head and neck carcinomas (stage III and IV) require combined oncological treatment consisting of surgery and CRT. The effect of such a treatment regime on the functioning of the immune system is especially interesting.

The aim of the present study was to evaluate the changes in the percentage levels of Treg lymphocytes in the blood samples of patients with head and neck squamous cell carcinoma before, during, and after combined treatment, RTH, chemotherapy (CTH), and CRT with respect to the stage of the disease and the intensity of the radiation reaction as monitored using the Dische scale [15].

\section{Material and methods}

The study included 20 patients with advanced head and neck squamous cell carcinoma (HPV-positive non-keratinising squamous cell carcinoma) stage III and IV treated between 2016 and 2017 in the Lukaszczyk Oncological Centre, Bydgoszcz, Poland. Convenient sampling was performed. The patients were selected for the study from the group of patients treated with combined oncological treatment (surgery, RTH, CTH). Each patient underwent surgery and RTH, or RTH and CTH, or surgery, RTH, and CTH (Table 1). Patients were treated according to the accepted management standard; in all cases, this involved combination treatment (surgery, RTH, and CTH). Table 1 shows the characteristics of the patient group.

The patient's consent was obtained in each case. Additionally, approval for the research program was granted by the Ethical Committee of the Nicolaus Copernicus University Ludwig Rydygier Collegium Medicum in Bydgoszcz (KBET/471/2016).

The intensity of the radiation reaction was monitored using the Dische scale [11].

Peripheral blood samples were collected from the 20 head and neck cancer patients prior to the combined oncological treatment (this involved CTH, RT, and CRT), during the treatment, after two weeks of therapy, and then one week after the completion of the treatment. The process of samples collection is presented graphically in Figure 1.

\section{Flow cytometry}

The samples for the cytometric evaluation of the Treg cell population in the whole blood of head and neck cancer patients (luminal A type) were prepared using Becton Dickinson reagents, according to the manufacturer's instructions. At first, the following antibodies for the detection of surface antigens were added to $100 \mu \mathrm{l}$ peripheral blood collected on EDTA: $5 \mu \mathrm{l} \mathrm{CD3} \mathrm{APC-Cy7,} 20 \mu \mathrm{l} \mathrm{CD} 4$ FITC, $20 \mu \mathrm{l} \mathrm{CD} 25$ APC, $5 \mu \mathrm{l} \mathrm{CD127} \mathrm{PerCP-Cy5.5,} \mathrm{and} 5 \mu \mathrm{l}$ CD194 PE-Cy7. After a 20-min incubation with mAbs (in the dark at RT), the cells were washed with $2 \mathrm{ml}$ of foetal bovine serum (FBS) buffer and centrifuged for $10 \mathrm{~min}$ at 
$250 \times \mathrm{g}$. The obtained cell pellet was fixed with $2 \mathrm{ml}$ of freshly prepared $1 \times$ buffer A (for $10 \mathrm{~min}$ at RT) and centrifuged for $5 \mathrm{~min}$ at $500 \times \mathrm{g}$. The cells were then washed with $2 \mathrm{ml}$ of FBS buffer $(5 \mathrm{~min}, 500 \times \mathrm{g}$ ) and permeabilised with $0.5 \mathrm{ml}$ of freshly prepared buffer $\mathrm{C}$ (for $30 \mathrm{~min}$ in the dark at RT). After two further washing steps (2 ml FBS; $5 \mathrm{~min}, 500 \times \mathrm{g}$ ), the cells were stained with $20 \mu \mathrm{l}$ of anti-human nuclear FoxP3 PE antibody for $30 \mathrm{~min}$ in the dark at room temperature. After two additional washing steps, the cells were suspended in $0.5 \mathrm{ml}$ of FBS buffer and analysed using a BD FACS Canto II flow cytometer and BD FACS Diva Software (Becton Dickinson). In each sample, $15,000-25,000 \mathrm{CD}^{+} / 4^{+}$cells were collected and the percentage of Treg lymphocytes determined according to the gating strategy described in the additional materials in the article by Santegoets et al. [12]. The Treg cells were considered to be $\mathrm{CD}^{+} / \mathrm{CD}^{+} / \mathrm{CD} 25^{+} / \mathrm{FoxP} 3^{+} / \mathrm{CD} 127(-/$ low $)$.

\section{Statistical analysis}

The distribution of variables in the study group of the patients with head and neck cancer checked with the use of the Shapiro-Wilk test showed that each of the patients was different from normal. The statistically significant differences between the groups were determined by the Kruskal-Wallis test, and one-way analysis of variance by ranks. The Mann-Whitney $U$ test was then used as applicable. All statistical analyses were carried out with the Statistica 8.0 software program (StatSoft Inc., Tulsa, OK, USA). A $p$-value $<0.05$ was considered indicative of a statistically significant difference.

\section{Results}

The percentage of $\mathrm{CD}^{+} / \mathrm{CD} 4^{+} / \mathrm{CD} 25^{+} / \mathrm{FoxP}^{+} /$ $\mathrm{CD} 127(-/$ low $) \mathrm{T}$ cells within the $\mathrm{CD}^{+} / \mathrm{CD}^{+} \mathrm{T}$ cell population was determined in all the examined blood samples derived from the patients with head and neck cancer after surgery and before RT/CRT (A), as well as during RT/CRT (B) and after completion of the treatment RT/ CRT (C) (Fig. 2).

A statistically significantly higher percentage of $\mathrm{CD}^{+} /$ $\mathrm{CD}^{+} / \mathrm{CD} 25^{+} / \mathrm{FoxP}^{+} / \mathrm{CD} 127$ (-/low) $\mathrm{T}$ cells within the $\mathrm{CD}^{+} / \mathrm{CD}^{+} \mathrm{T}$ cell population was detected in patients during RTH and CRT than before the treatment began $(p<0.0001)$ (Fig. 2).

A statistically significantly higher percentage of $\mathrm{CD}^{+} /$ $\mathrm{CD}^{+} / \mathrm{CD} 25^{+} / \mathrm{FoxP}^{+} / \mathrm{CD} 127(-/$ low) $\mathrm{T}$ cells within the $\mathrm{CD}^{+} / \mathrm{CD}^{+} \mathrm{T}$ cell population was detected in patients during RTH/CRT than after the completion of the treatment $(p<0.0001)$ (Fig. 2).

A statistically significantly higher percentage of $\mathrm{CD}^{+} /$ $\mathrm{CD}^{+} / \mathrm{CD} 25^{+} / \mathrm{FoxP}^{+} / \mathrm{CD} 127(-/$ low) $\mathrm{T}$ cells within the $\mathrm{CD}^{+} / \mathrm{CD} 4^{+} \mathrm{T}$ cell population was detected before $\mathrm{RTH} /$ $\mathrm{CRT}$ than after treatment with respect to the radiation re-

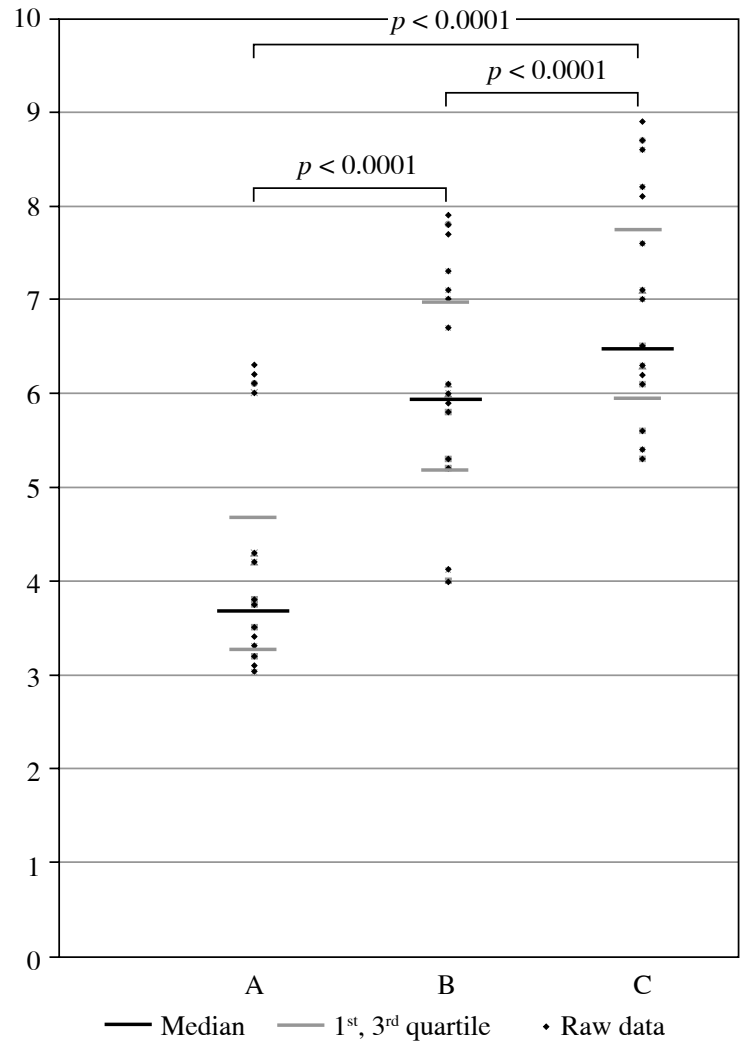

Fig. 2. The percentage of $\mathrm{CD}^{+} / \mathrm{CD}^{+} / \mathrm{CD} 25^{+} / \mathrm{FoxP}^{+} /$ CD127(-/low) $\mathrm{T}$ cells within $\mathrm{CD}^{+} / \mathrm{CD}^{+} \mathrm{T}$ cell population in blood samples derived from patients with head and neck cancer after surgery and before radiotherapy (RTH)/chemoradiotherapy (CRT) (A), as well as during RTH/CRT (B), and after completion of the RTH/CRT (C) treatment

action as evaluated using the Dische scale $(p=0.0150)$. The increase in the percentage of Treg cells correlated with an increase in the intensity of the radiation reaction measured using the Dische scale (in points), which indicates the advance of the oral mucositis reaction to RTH (Fig. 3).

We observed no statistically significant differences in the percentage of $\mathrm{CD}^{+} / \mathrm{CD}^{+} / \mathrm{CD} 25^{+} / \mathrm{FoxP}^{+} / \mathrm{CD} 127(-/ \mathrm{low})$ $\mathrm{T}$ cells within the $\mathrm{CD}^{+} / \mathrm{CD}^{+} \mathrm{T}$ cell population before and after the treatment, or in the increase of the percentage of these cells during the treatment with respect to age, gender, stage of the disease (S), presence of lymph node metastases $(\mathrm{N})$, tumour size $(\mathrm{T})$, and lymph node status (N0 + N1 vs. N2).

\section{Discussion}

In the present study a progressive statistically significant increase in the blood percentages of $\mathrm{CD}^{+} / \mathrm{CD}^{+} /$ CD25+/FoxP3+/CD127(-/low) $\mathrm{T}$ cells within the $\mathrm{CD}^{+}{ }^{+} /$ $\mathrm{CD}^{+} \mathrm{T}$ cell population was detected in patients during 


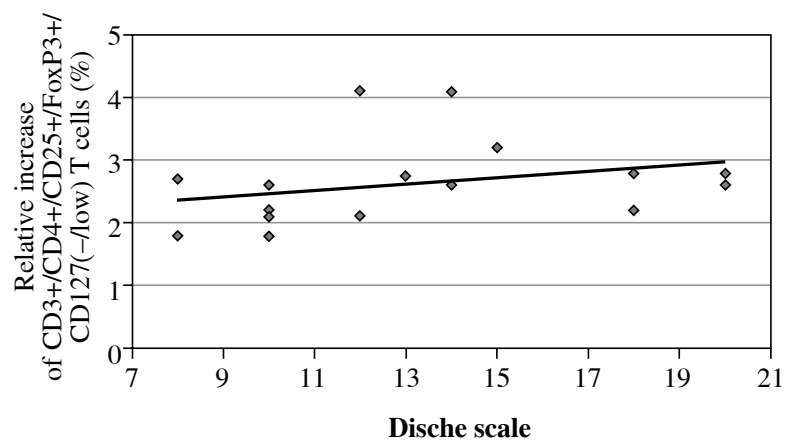

Fig. 3. The percentage of $\mathrm{CD}^{+} / \mathrm{CD}^{+} / \mathrm{CD} 25^{+} / \mathrm{FoxP}^{+} /$ $\mathrm{CD} 127(-/$ low $) \mathrm{T}$ cells within the $\mathrm{CD}^{+} / \mathrm{CD}^{+} \mathrm{T}$ cell population in patients with head and neck cancer after surgery, before radiotherapy (RTH)/chemoradiotherapy (CRT), during RTH/CRT, and after the completion of the treatment, with respect to radiation reaction evaluated using the Dische scale

treatment (RT, CHTH, and CRT) compared to the percentages of these cells before treatment. The highest Treg cell percentages were observed in patients after therapy. This observation corresponds with the results of our previous studies concerning patients with ovarian and endometrial cancers, where the percentages of $\mathrm{CD} 4{ }^{+} \mathrm{CD} 25^{+} \mathrm{FOXP} 3^{+}$ $\mathrm{T}$ cells were significantly lower following surgical treatment than before. In the patients with breast cancer, we observed a significantly lower percentage of $\mathrm{CD} 25^{+} /$ FoxP3 ${ }^{+} / \mathrm{CD} 127\left(^{-} /\right.$low $) \mathrm{T}$ cells within the CD3+/CD4+ $\mathrm{T}$ cell population in the blood samples taken after surgical treatment than those taken before surgery, as well as an increase following the completion of RTH [2, 18-20]. Albers et al. observed a significant increase in the blood percentage of $\mathrm{CD} 4{ }^{+} \mathrm{CD} 25^{+}$lymphocytes among TIL (tumour infiltrating lymphocytes) in head and neck cancer patients [21]. Both elevated percentages and suppressor activity of Treg cells were observed in those patients who had suffered from head and neck squamous cell carcinoma but had no evident disease following CRT [22]. Untreated patients with active disease had a significantly higher frequency of circulating Treg cells in the blood than normal donors, and the treatment ( $\mathrm{CTH}$ and $\mathrm{RTH})$ increased the frequency and function of these cells [10]. The meaning of the function of Treg lymphocytes in post-treatment patients is unknown [20]. Schuler et al. have suggested that persistent Treg cells induced by surgery and CRT in head and neck cancer patients result in the suppression of antitumour immune effector cells and thus promote disease recurrence or the development of secondary cancers [10]. Many authors suggest that patients might benefit from a combination of RT and CRT with Treg-targeting agents to maximise antitumor efficacy. Ma et al. studied the effect of the partial depletion of Treg cells using an anti-CD25 antibody prior to radiation in mice. Because there was no influence on the inflammatory response, the authors concluded that anti-CD25 therapy with radiation may be safe and well tolerated in cancer patients [23].

In the present study, the percentages of $\mathrm{CD}^{+} / \mathrm{CD}^{+} /$ $\mathrm{CD}_{25} /$ FoxP3 $3^{+/ C D} 127(-/$ low $) \mathrm{T}$ cells within the $\mathrm{CD}^{+} /$ $\mathrm{CD} 4^{+} \mathrm{T}$ cell population were significantly correlated with the radiation reaction measured on the Dische scale, which confirms that an inflammatory reaction induced by radiation increases the percentage of Treg cells. Dai et al. also reported an elevation of Treg blood percentages following radiochemotherapy in nasopharyngeal cancer patients with respect to radiation reaction [23]. Treg cells are responsible for preventing excessive immune responses. They down-regulate pro-inflammatory responses in patients following RTH, which may prevent tissue damage from increasing as a reaction to the radiation [20].

\section{Conclusions}

In summary, because the role of Treg lymphocytes in cancer patients is complex and the therapeutic depletion of these cells requires a better understanding of their role in cancer, it is necessary to monitor the percentages of these cells in patients during combined oncological therapies.

The limitation of the study is the convenient selection of patients with advanced stages of the disease. The patients were selected from the group of patients treated with combined oncological treatment (surgery, RTH, $\mathrm{CTH}$ ). The complex oncological treatment, in particular $\mathrm{RTH}$ and $\mathrm{CTH}$, exert a radiation reaction - an excessive inflammatory reaction, involving the population of Treg cells. This might also influence the patients' outcome. We aimed to evaluate the potential influence of the treatment on the Treg blood percentages and link them with the radiation reaction measured with the Dische scale. Patients suffering from head and neck cancer in I and II stage of the disease commonly require only sole surgery or sole RTH; most commonly, patients who require surgery, $\mathrm{CTH}$, and RTH represent advanced stages of the disease. As a result, our group of patients comprised patients with advanced stages of the disease.

\section{Acknowledgements}

This study was funded by the Lukaszczyk Oncological Centre, Bydgoszcz, Poland (grant number 37/2015).

The authors declare no conflict of interest. 


\section{References}

1. Whiteside TL (2018): FOXP3+ Treg as a therapeutic target for promoting anti-tumor immunity. Expert Opin Ther Targets 22: 353-363.

2. Dutsch-Wicherek M, Kazmierczak W (2013): Creation of a suppressive microenvironment by macrophages and cancerassociated fibroblasts. Front Biosci (Landmark Ed) 18: 10031016.

3. Kazmierczak W, Lazar A, Tomaszewska R, et al. (2015): Analysis of the intensity of immune cell infiltration and immunoreactivity of RCAS1 in diffuse large B-cell lymphoma of the palatine tonsil and its microenvironment. Cell Tissue Res 361: 823-831.

4. Dutsch-Wicherek M, Lazar A, Tomaszewska R, et al. (2013): Analysis of metallothionein and vimentin immunoreactivity in pharyngeal squamous cell carcinoma and its microenvironment. Cell Tissue Res 352: 341-349.

5. Kuss I, Hathaway B, Ferris RL, et al. (2004): Decreased absolute counts of $\mathrm{T}$ lymphocyte subsets and their relation to disease in squamous cell carcinoma of the head and neck. Clin Cancer Res 10: 3755-3762.

6. Hoffmann TK, Dworacki G, Tsukihiro T, et al. (2002): Spontaneous apoptosis of circulating $\mathrm{T}$ lymphocytes in patients with head and neck cancer and its clinical importance. Clin Cancer Res 8: 2553-2562.

7. Kuss I, Donnenberg AD, Gooding W, et al. (2003): Effector CD8+CD45RO-CD27-T cells have signaling defects in patients with squamous cell carcinoma of the head and neck. Br J Cancer 88: 223-230.

8. Schaefer C, Kim GG, Albers A, et al. (2005): Characteristics of CD4+CD25+ regulatory $\mathrm{T}$ cells in the peripheral circulation of patients with head and neck cancer. Br J Cancer 92: 913-920.

9. Wiśniewski M, Koper K, Łukaszewska E, et al. (2011): Changes in the Treg lymphocyte population levels in patients being treated for ovarian cancer with chemotherapy. Curr Gynecol Oncol 9: 136-146.

10. Schuler PJ, Harasymczuk M, Schilling B, et al. (2013): Effects of adjuvant chemoradiotherapy on the frequency and function of regulatory $\mathrm{T}$ cells in patients with head and neck cancer. Clin Cancer Res 19: 6585-6596.

11. Dische S, Warburton MF, Jones D, et al. (1989): The recording of morbidity related to radiotherapy. Radiother Oncol 16: 103-108.

12. Santegoets SJ, Dijkgraaf EM, Battaglia A, et al. (2015): Monitoring regulatory $\mathrm{T}$ cells in clinical samples: consensus on an essential marker set and gating strategy for regulatory $\mathrm{T}$ cell analysis by flow cytometry. Cancer Immunol Immunother 64: 1271-1286.

13. Postow MA, Callahan MK, Barker CA, et al. (2012): Immunologic correlates of the abscopal effect in patient with melanoma. N Engl J Med 366: 925-931.

14. Sharabi AB, Kochel CM, Nirschl CJ, et al. (2015): Stereotactic radiation therapy augments antigen specific PD-1mediated antitumor immune responses via cross-presentation of tumor antigen. Cancer Immunol Res 3: 345-355.

15. Kachikwu EL, Iwamoto KS, Liao YP, et al. (2011): Radiation enhances regulatory $\mathrm{T}$ cell representation. In $\mathrm{J}$ Radiat Oncol Biol Phys 81: 1128-1135.

16. Muroyama Y, Nirschl TR, Kochel CM, et al. (2017): Stereotactic radiotherapy increases functionally suppressive regulatory $\mathrm{t}$ cells in the tumor microenvironment. Cancer Immunol Res 5: 992-1004.
17. Wicherek L, Jozwicki W, Windorbska W, et al. (2011): Analysis of Treg cell population alterations in the peripheral blood of patients treated surgically for ovarian cancer - a preliminary report. Am J Reprod Immunol 66: 444-450.

18. Walentowicz-Sadlecka M, Dziobek K, Grabiec M, et al. (2019): The analysis of human leukocyte antigen-G level in patients with endometrial cancer by Western blot technique. Am J Reprod Immunol 81: e13070. doi: 10.1111/aji.13070.

19. Whiteside TL (2014): Regulatory T cell subsets in human cancer: are they regulating for or against tumor progression? Cancer Immunol Immunother 63: 67-72.

20. Strauss L, Bergmann C, Whiteside TL (2007): Functional and phenotypic characteristics of CD4+CD25highFoxp3+ Treg clones obtained from peripheral blood of patients with cancer. Int J Cancer 121: 2473-2483.

21. Albers AE, Ferris RL, Kim GG, et al. (2005): Immune responses to p53 in patients with cancer: enrichment in tetramer+ p53 peptide-specific $\mathrm{T}$ cells and regulatory $\mathrm{T}$ cells at tumor sites. Cancer Immunol Immunother 54: 1072-1081.

22. Ma S, Richardson JA, Bitmansour A, et al. (2013): Partial depletion of regulatory t cells does not influence the inflammation caused by high dose hemi-body irradiation. PLoS One 8: e56607.

23. Dai XC, Liu LQ, Wang BH, et al. (2017): Effect of concurrent chemoradiotherapy and radiotherapy alone on peripheral myeloid-derived suppressor and $\mathrm{T}$ regulatory cells in patients with nasopharyngeal cancer. Zhonghua Zhong Liu Za Zhi 39: 579-583. 